\title{
The Impact of Net Worth on Inequality in Economic Mobility Since COVID-19
}

\author{
Jaewon Lee ${ }^{1 *}$ and Jennifer Allen ${ }^{2}$ \\ ${ }^{1}$ Department of Social Welfare, Inha University, South Korea \\ ${ }^{2}$ School of Social Work, Michigan State University, USA \\ *Corresponding author: Jaewon Lee, Assistant Professor, Department of Social Welfare, Inha University, 100 Inha-ro, Michuhol-gu, \\ Incheon 22212, South Korea.
}

To Cite This Article: Jaewon Lee, Jennifer Allen. The Impact of Net Worth on Inequality in Economic Mobility Since COVID-19. Am J Biomed Sci \& Res. 2021 - 13(5). AJBSR.MS.ID.001903. DOI: 10.34297/AJBSR.2021.13.001903.

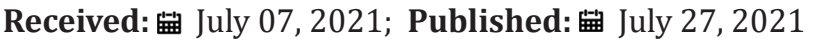

\section{Challenges In Upward Mobility Since COVID-19}

Wealth has been given attention as one of the factors leading to increased economic inequality [1,2]. Net worth affects the lives of low-income families because they have had disadvantages in accessing economic activities and less opportunity to accumulate their own assets. The lack of asset accumulation thus restricts economic mobility across low-income individuals [3]. For instance, in one study it was found that female-headed households had lower economic mobility than other households, and that single-mothers experienced limited opportunities for economic mobility due to the lack of asset accumulation [4]. Therefore, given the importance of assets for economic mobility, it is imperative to construct new welfare policies that assists people in accumulating assets [4,5], particularly for those who have faced severe economic challenges since coronavirus disease-19 (COVID-19).

Since the COVID-19 pandemic, it is much more difficult for people with lower socioeconomic status (SES) to move to upper classes because the pandemic has made it more challenging to earn a living and be employed. The lower SES groups were less likely to accumulate wealth even before COVID-19, and this phenomenon has become even more serious since coronavirus disease. As unemployment rates dramatically increased around the world since COVID-19, persons with disabilities, single mothers, and other disadvantaged groups have been exposed to severe financial difficulties. However, wealthy individuals and corporations can still save their money and increase their assets even during COVID-19 (e.g., Amazon). That is, the polarization between upper and bottom class has seriously increased since COVID-19, indicating that there are much fewer opportunities for lower SES groups to increase their SES. The underlying reason that the financial difficulties of lower SES groups have become worse since COVID-19 is that they have a lower accumulated net worth, which would help buffer against temporary financial hardships caused by the COVID-19 pandemic.

\section{Net Worth as A Source of Economic Well-Being}

Economic well-being can be defined as the satisfaction of basic needs acquired through the labor market [6]. Economic well-being is a broad concept that includes the following: economic hardships, difficulties, or challenges, such as trouble paying bills; individual unsatisfied needs of economic resources; and the inability to satisfy the household's basic needs [7]. As net worth includes accumulated and integrated wealth as individuals use household resources, such as financial and real assets, to maximize their well-being [8], individuals' assets or debts are important in measuring their economic well-being.

The assets perspective regards achieving economic well-being as a long-term and active process. Compared to income, net worth has long-term effects on economic well-being because it considers lifetime financial accumulation rather than a cross-sectional view of an individual's financial status [5]. On the other hand, income refers to one's immediate financial resources for daily necessities, such as food, clothing, and housing [5]. That is, even though both income and assets are types of financial resources, they are different in terms of time frames, and there is a distinction between income and assets $[9,4]$. Assets are more important than income for immediate consumption because it ensures security [3]. Thus, 
using net worth might be better than income or other economic factors to understand economic well-being because it addresses lifetime or long-term effects [9].

\section{Conclusion}

As net worth indicates accumulation of wealth over time, individuals with greater wealth are less likely to end up in poverty during financial disasters such as the COVID-19 pandemic. In other words, wealthy people with a higher accumulated net worth are more easily able to overcome the financial hardships of the COVID-19 pandemic based on their economic resources, while poor people with fewer assets have troubles maintaining their standard of living. This leads to more serious inequality in economic mobility. Therefore, the government should provide a tailored-antipoverty program to those with few accumulated assets as well as educational programs about saving economic resources. Further, the social safety net should be expanded to protect them from economic difficulties during COVID-19.

\section{References}

1. Keister L A (2000) Wealth in America: Trends in Wealth Inequality Cambridge, UK: Cambridge University Press.
2. Wolff E N (2000) Recent trends in wealth ownership, 1983-1998. Working Paper No. 300. Annandale-on-Hudson, NY: The Jerome Levy Economics Institute.

3. Zhan M (2006) Economic mobility of single mothers: The role of assets and human capital development. Journal of Sociology and Social Welfare 33: $127-150$.

4. Sherraden M (2015) Assets and the poor: A new American welfare policy. New York, NY: Routledge.

5. Sherraden M (1990) Stakeholding: Notes on a theory of welfare based on assets. Social Service Review 64(4): 580-601.

6. Sumner A (2006) Economic well-being and non-economic well-being. In M. McGillivray \& M. Clarke, Understanding human well-being. Pp 54-73.

7. Pearlin L I, Lieberman M A, Menaghan E G, Mullan J T (1981) The stress process. Journal of Health and Social Behavior 22: 337-356.

8. Clark R L (1989) Economic well-being of the elderly: Theory and measurement. J Cross Cult Gerontol 4(1): 19-34.

9. Oliver M L, Shapiro T M (2006) Black wealth/White wealth: A new perspective on racial inequality. New York: Routledge. 